\title{
"Challenges impeding women into leadership roles in a student-led organization at a South African higher education institution"
}

\begin{tabular}{|c|c|}
\hline AUTHORS & $\begin{array}{l}\text { Nokwanda Jali (iD) } \\
\text { Sachin Suknunan (iD) } \\
\text { Anrusha Bhana (iD) } \\
\text { R }\end{array}$ \\
\hline ARTICLE INFO & $\begin{array}{l}\text { Nokwanda Jali, Sachin Suknunan and Anrusha Bhana (2021). Challenges } \\
\text { impeding women into leadership roles in a student-led organization at a South } \\
\text { African higher education institution. Problems and Perspectives in Management, } \\
\text { 19(4), 508-518. doi:10.21511/ppm.19(4).2021.41 }\end{array}$ \\
\hline DOI & http://dx.doi.org/10.21511/ppm.19(4).2021.41 \\
\hline RELEASED ON & Wednesday, 29 December 2021 \\
\hline RECEIVED ON & Wednesday, 20 October 2021 \\
\hline \multirow[t]{2}{*}{ ACCEPTED ON } & Tuesday, 23 November 2021 \\
\hline & $(c)$ EY \\
\hline LICENSE & $\begin{array}{l}\text { This work is licensed under a Creative Commons Attribution } 4.0 \text { International } \\
\text { License }\end{array}$ \\
\hline JOURNAL & "Problems and Perspectives in Management" \\
\hline ISSN PRINT & $1727-7051$ \\
\hline ISSN ONLINE & $1810-5467$ \\
\hline PUBLISHER & LLC "Consulting Publishing Company "Business Perspectives" \\
\hline FOUNDER & LLC "Consulting Publishing Company "Business Perspectives" \\
\hline & 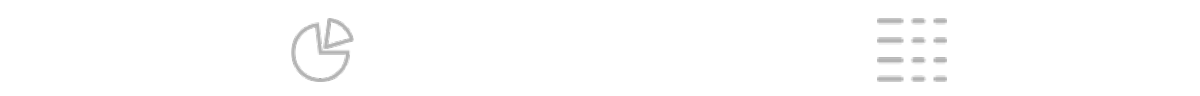 \\
\hline NUMBER OF REFERENCES & NUMBER OF FIGURES \\
\hline 40 & 3 \\
\hline
\end{tabular}

(c) The author(s) 2021. This publication is an open access article. 


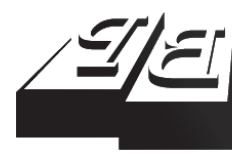

\section{BUSINESS PERSPECTIVES}

()

LLC "CPC "Business Perspectives" Hryhorii Skovoroda lane, 10, Sumy, 40022, Ukraine www.businessperspectives.org
Received on: $20^{\text {th }}$ of October, 2021 Accepted on: $23^{\text {rd }}$ of November, 2021 Published on: $29^{\text {th }}$ of December, 2021

(๑) Nokwanda Jali, Sachin Suknunan, Anrusha Bhana, 2021

Nokwanda Jali, Master of Commerce, Student Services Division, University of KwaZulu-Natal, South Africa.

Sachin Suknunan, Doctor of Business Administration, Student Services Division, University of KwaZulu-Natal, South Africa. (Corresponding author)

Anrusha Bhana, Ph.D., Senior Lecturer Faculty of Accounting and Informatics, Department of Financial Accounting. Durban University of Technology, South Africa.
Nokwanda Jali (South Africa), Sachin Suknunan (South Africa), Anrusha Bhana (South Africa)

\section{CHALLENGES IMPEDING WOMEN INTO LEADERSHIP ROLES IN A STUDENT-LED ORGANIZATION AT A SOUTH AFRICAN HIGHER EDUCATION INSTITUTION}

\begin{abstract}
The study shows that a patriarchal society where women are still in the minority when it comes to leadership positions is still dominating. A few studies are exploring the role of women in leadership in government and industry, and very little focus is paid on higher education institutions and more especially - from a female leadership perspective. Therefore, this paper aims to determine the factors that hindered female students from attaining leadership positions and simultaneously make recommendations to create more leadership opportunities in a nationally recognized student-led organization known as the Student Representative Council at a large public South African higher education institution - the University of KwaZulu-Natal. The target population was 16 female leaders who served in the University's Student Representative Council from 2019 to 2020 of which 13 had responded. A qualitative approach was followed and interviews were conducted. The study employed inductive qualitative thematic analysis using NVIVO 12. Findings revealed that the Student Representative Council structure at the university was patriarchal with little commitment to gender equality. Males outnumbered women in leadership roles. Portfolios assigned to women were mainly administrative rather than leadership. Females were subjected to stereotypical behavior. The study recommended ways to promote female student leadership whereby policy and constitution change is required to facilitate gender equality and the implementation of quotas. Women should be empowered to enhance their leadership skills via effective leadership development programs specifically designed for females to address the leadership gap between males and females.
\end{abstract}

\section{Keywords university, transformation, equality, empowerment, policy, qualitative}

\section{JEL Classification I23, L25, L38, M14}

\section{INTRODUCTION}

Women have always aspired to leadership positions as opportunities are increasingly presenting themselves. However, women continue to face discrimination and are in the minority when it comes to assuming leadership positions and performing their roles in the public and private domain (Evans et al., 2014). This paper sets out to establish the main factors that hinder female students from attaining leadership positions within a higher education environment and focuses more on an organizational perspective of student leadership. There is a vast amount of literature primarily with a focus on women leadership in the workplace (Ackerman \& Velelo, 2015; Evans, 2016a, 2016b; Keen \& Cracknell, 2016; Zuber, 2015). However, there is still minimal scholarly literature that focuses on women in student leadership roles, particularly those leading in the Student Representative Council (SRC) within higher education institutions (HEIs) in South Africa (SA). While women are slowly gaining access to leadership positions in various 
sectors, the roles are still highly male-dominated and are continually ring-fenced for males (Evans, 2016a). Research exploring the role of women in the various spheres of life has increased. However, there is very little focus on women's role in student-led organizations within higher education, more specifically - universities. The SRC is a legislated governance structure in all South African universities, according to Section 35 of the Higher Education Act No. 101 as of 1997, as amended. Statistics extracted from the Institutional Intelligence at the respondent institution, the University of KwaZuluNatal (UKZN), revealed that the female student population outnumbered the male student population between 2015 and 2020 (UKZN, n.d.). Furthermore, even countrywide, it was found that across 26 nationally recognized universities there were only 3 institutions with female SRC presidents (SAUS, n.d.). At the respondent institution, women still run for election into SRC every year for leadership positions; the minority who are elected generally do not get representation into the positions of power, influence, and decision-making. Therefore, there is a need to examine factors that impeded female students from attaining leadership positions in the SRC at UKZN and determine ways to overcome such challenges and promote more women into leadership roles.

\section{LITERATURE REVIEW}

Various states commended South Africa for establishing policy frameworks to address all sorts of inequalities. Such policies created platforms for women to be actively engaged in matters, which pertain to their livelihood (Gouws, 2010). Enforcement of legal reforms translated to increased representation of women in leadership positions in various sectors (Evans, 2016a; Keen \& Cracknell, 2016). Some of the acts are as follows: Women Empowerment and Gender Equality Bill (as of 2013), Promotion of Equality and Prevention of Unfair Discrimination Act No. 4 (as of 2000), and Employment Equity Act No. 55 (as of 1998). The global political leadership is still trapped in patriarchy with male leadership enjoying dominant representation in politics. Maphosa et al. (2015) and Kasomo (2012) argued that the underrepresentation of women in politics is not accidental, but is an intentional and seriously calculated move that is systematically and deeply interwoven in societal beliefs. Francis (2009) and Chizema et al. (2015) agreed that women's own negative perception of their role in political leadership compounds their lack of representation. Furthermore, lack of representation of women in the political sector is ascribed to various factors such as gender stereotyping, lack of empowerment, and lack of information and proper counselling for women (Lawless \& Fox, 2013; Schneider et al., 2016). Moor et al. (2015) argue that the male-orientated organizational culture delivers additional barriers for women. Consequently, women have to work harder or even double the effort to prove themselves as capable to hold such positions. The survey results of the non-financial census of municipalities conducted by Statistics South Africa (2016) demonstrate negligible progress made from 2011 to 2015 in gender representation in local government elections. Women holding mayoral positions stood at $38 \%$ in 2015 . This figure reached $42 \%$ during the 2011 local municipal elections (Statistics South Africa, 2016). However, the 2016 municipal elections produced improved results showing commitment by political parties to have more women in the local structures (Vetten, 2016).

United Nations (2015) noted high rates of unemployment among women in Sub-Saharan Africa, Northern Africa, Southern Europe, and Western Asia in 2013. Globally, males have generally maintained higher employment rates than females, and consequently, unemployment rates are higher for women as compared to men (United Nations, 2015). Consequently, women's participation and representation as the leadership in the workforce, including representation in high decision-making structures such as corporate boards of directors, executive and managerial portfolios, is still persistently low (Chizema et al., 2015). The decisions made in the absence of women have a bearing and influence on a whole range of issues, which affect women, such as the implementation of labor laws, economic policies, and education policies (Soklaridis \& Lopez, 2014). It is important to have the voice of women in decision-making, who largely form more than half of the world population (United Nations, 2017). Dormehl (2012) claimed that organizations, which engage wom- 
en, enjoy a diversified workforce, helping organizations to comply and meet organizational goals. Not only do these organizations address issues of gender diversity but they also tap into women's diverse skills and intellect. Phakeng (2015) argued that the increased representation of women in government might paint a misleading picture about equality between men and women, while other sectors are still struggling and far from achieving this. Women have relevant qualifications and experience to tackle issues in a male-dominated field and contribute to finding innovative solutions.

The private and academic sectors, amongst others, are still experiencing sluggish growth despite the legislature, which should promote equality (Phakeng, 2015). Many women in these sectors are still employed at lower-skilled occupation levels (Mabokela, 2003; Ackerman \& Velelo, 2015). Achievements vary across sectors; hence, improvement cannot be broadly aggregated. Miles (2010) examined female student government presidents' reflections, in which five female student government association presidents were interviewed. They served as presidents from various higher education institutions in the Western Region in the United States of America (USA). The holistic findings implied that women were not equally represented in student leadership. The study established that female students derived benefits from their leadership experiences, such as communication, planning and organizing, and interpersonal skills. The experience contributed immensely to preparing them for their careers. On the other side, they also faced various complexities of the leadership role and being a full-time student at the same time. They faced challenges such as time management, balance between performing their leadership tasks effectively and academic performance, and learning and understanding their structures and the institutional structure. They were frustrated by expectations from their peers and the fact that "they had to navigate the bureaucracy of their institution to accomplish specific goals or implement programs" (Miles, 2010, pp. 4-9).

BlackChen (2015) asserted that lack of women empowerment contributes to the shortage of women in the HE sector leadership roles. Higher education institutions (HEIs) are regarded as places of enlightenment and knowledge production. It is against this background that one fails to understand how these institutions, despite being front-runners of transformation, still have student leadership structures that are severely gender skewed. This phenomenon seems to be standard across South African universities' SRC structures and may influence how various leadership teams are structured within them.

The SRC at UKZN is the highest student governance structure established in terms of section 35 of the Higher Education Act No. 101 as of 1997, as amended. The SRC's primary function at UKZN is to represent, serve, and advocate for students individually and collectively as a UKZN student body in matters affecting them, impinging their rights and general welfare. The SRC, therefore, operates in a social movement environment that is perceived to be politically driven. In addition, in South Africa (SA), there is a national SRC overarching body known as the South African Union of Students (SAUS). It combines SRC presidents of all the 26 public universities and TVETs, despite their political, religious, and cultural beliefs. Its vision is "to organize all the students in higher learning institutions through student representative councils and make education accessible to all” (SAUS, n.d.).

The SRCs in South African higher education operate in a predominantly politicized environment. Lawless and Fox (2013) highlighted that women's perception of themselves feeling unqualified to run for an office is a barrier that causes them to avoid standing for political nomination. Further, Lawless and Fox (2013), Schneider et al. (2016), Greyling and Steyn (2015), and Greenlee et al. (2014) revealed that among numerous other factors that prevented women to seize opportunities to stand for nomination into leadership positions were that women were not encouraged to run for office and are not politically persuaded. In addition, the political ambition of women was outweighed by men's political ambition. The experience of women in the competitive political debate was seen as weak whilst men had a strong desire to win and were more competitive in politics. Similarly, Gwirayi (2010) looked at the influence of gender on access to leadership positions. The study was conducted in the SRC among final year students at a Zimbabwean college. Among other factors, it aimed to understand students' criteria to elect their SRC. The study findings 
demonstrated that women were still marginalized, perpetuating women's leadership gap, and gender inequality. The study also highlighted institutional role in perpetuating inequality and institutional authorities need to ensure female representation in every SRC.

Lawless and Fox (2013), Miller and Kraus (2004), and Gwirayi (2010) converge on various important points. These points highlight that patriarchy still prevailed in HE, achievement came with aggression and was still masculine, and that educated women (equally qualified as men) still lacked courage and perceived themselves as ineligible for leadership positions. The aggression, as mentioned above, was evident even in their actions, jargon, and tone of communication during campaigns for elections, such as raising a clenched fist, citing words such as 'fighting, the struggle, comrade, chief' among others. These actions and words in their very nature are very masculine and intimidating for women (Lawless \& Fox, 2013). Political activism requires many public appearances and for women, this means being away from home and family most of the time. Gwirayi (2010) and Lawless and Fox (2013) agreed that these prevailing forces contribute to women's lack of motivation and confidence to stand for nomination into public leadership positions. Gwirayi (2010) further argued that society tends to predefine gender roles, which are accepted as a societal norm, and each gender is therefore groomed accordingly. These societal beliefs and perceptions oppress women more as opposed to men and must be eliminated. Furthermore, an analysis of the Universities South Africa (USAf is an overarching body of all the 26 public universities) website was conducted in October 2020 to look into the composition of the SRCs of individual universities. The investigation revealed that males dominated the SRC structures. Out of the 26 public universities in South Africa, it was found that only three universities had a female SRC president (USAf, n.d.).

The literature review provided an insight into the role of women leaders both in public and private spheres. Whilst women have made gradual progress into accessing leadership positions, the literature reviewed indicates that barriers still exist, the glass ceiling is unbreakable. Patriarchy and women stereotyping dominate and preclude women based on gender. The introduction of gen- der equity policies, gender quota legislation, and other frameworks that were developed to persuade organizations to support women's access to leadership have not yielded the results. Thus, most literature concludes that women still face discrimination and are underrepresented in leadership positions both locally and globally.

The aim of this paper is therefore to determine the factors that have hindered women from attaining leadership positions in the SRC at UKZN and simultaneously make recommendations to create more leadership opportunities for women in the SRC.

\section{METHODS}

The University of KwaZulu-Natal was chosen as a target university. This university has approximately 50,000 students and is one of the largest universities in South Africa. A census approach was selected whereby the entire population of female students who served as portfolio leaders within the SRC between 2019 and 2020 was targeted. This amounted to a total of 16 respondents. Given the limited population of 16 women in the university SRC, a qualitative method was therefore employed to collect rich data, which allowed for further deep interpretation. All interviews were conducted telephonically in 2020 due to COVID-19 regulations, which prevented face-to-face interactions. There were 13 interview responses (out of 16) giving a response rate of $81 \%$.

\section{RESULTS}

The demographic profile of the respondents is presented through the use of descriptive statistics.

The results in Figure 1 reflect that respondents were between 21-31 years, with ages 22 and 25 contributing the largest proportion of participant age. Therefore, this indicates that the participants were mature and experienced to be engaged in socio-political debates and handle matters that affected students at their campus effectively and competently.

Figure 2 depicts the wide-ranging and diverse qualifications inclusive of education, medicine, 


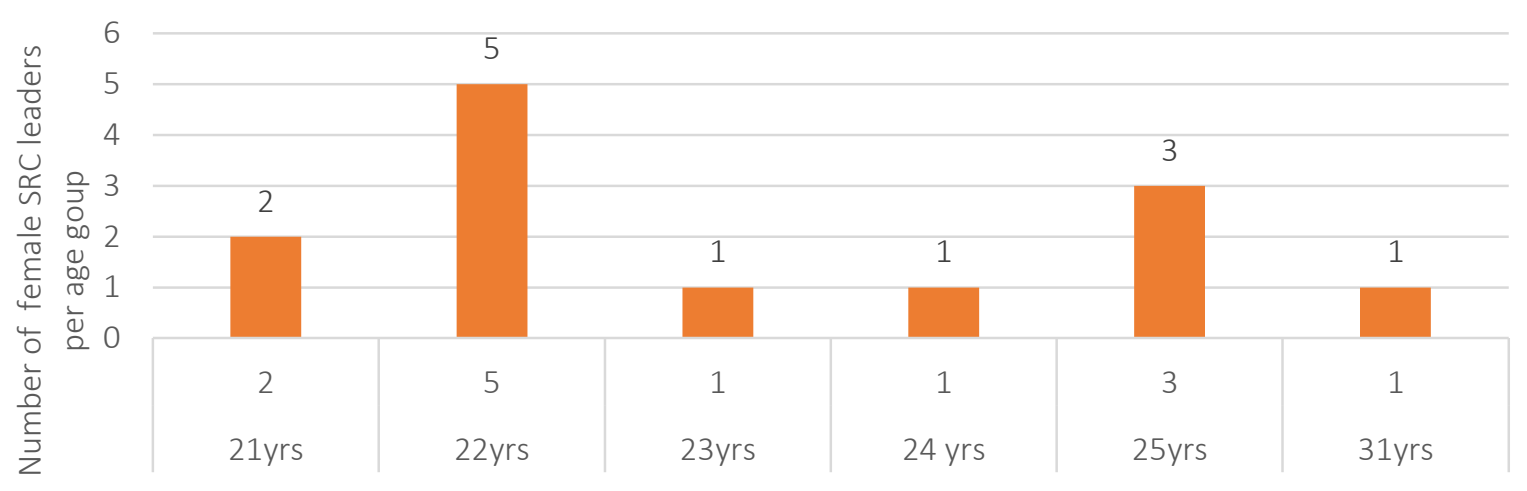

Different age groups of female SRC leaders

Figure 1. Age

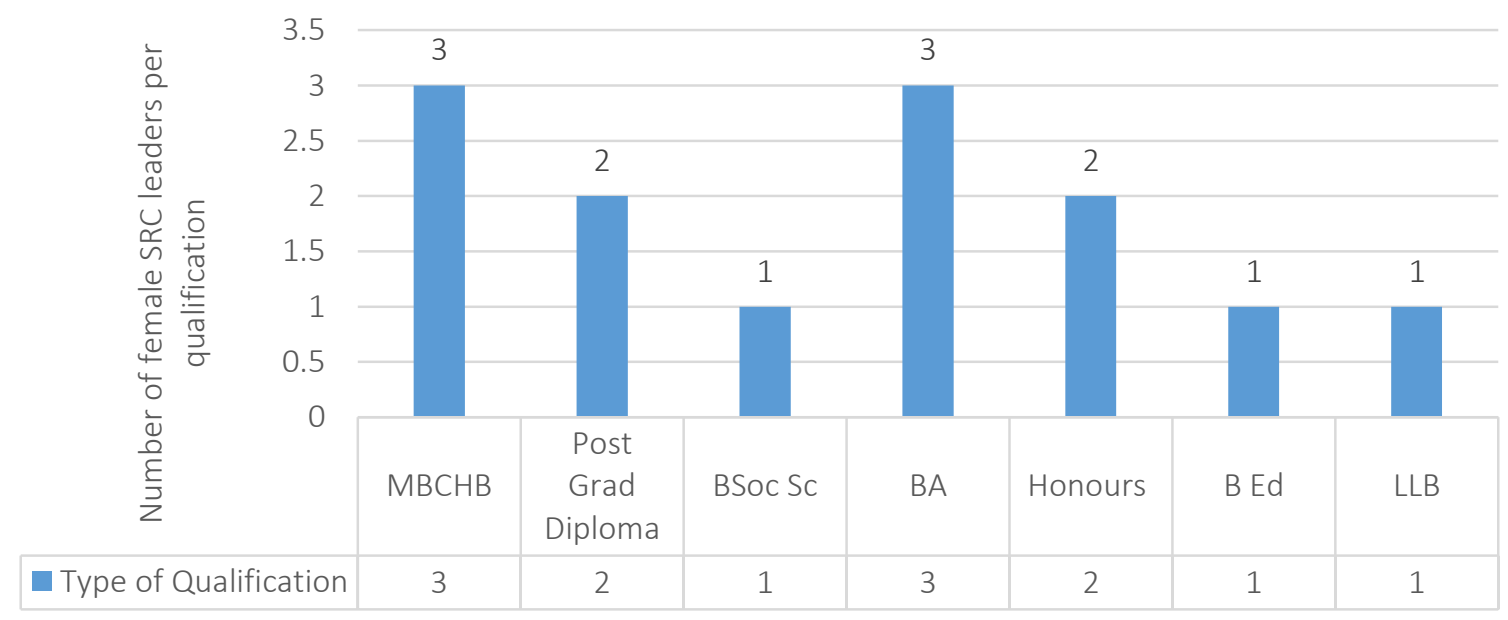

Figure 2. Qualification

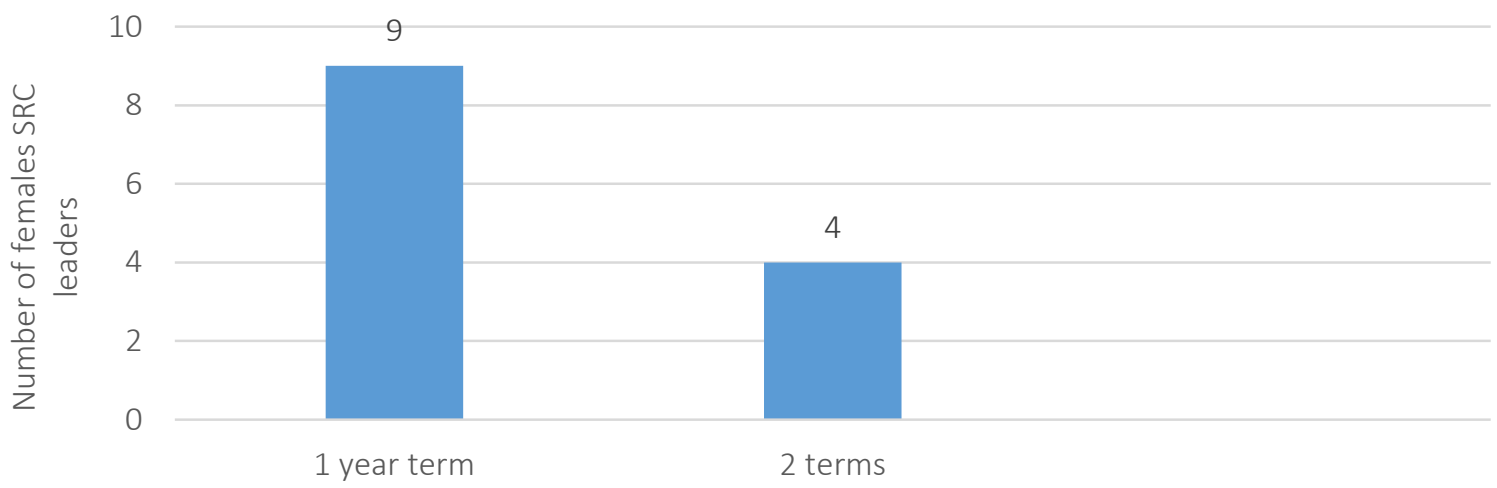

Figure 3. Length of service in the SRC

law, social sciences, and postgraduate studies in which the respondents were enrolled.

Figure 3 shows that 9 out of 13 respondents had served only one term of office, whereas only 4 had served two terms of office.

\subsection{Current role occupied by women in the SRC}

It was found that the main roles occupied by women within the SRC are more administrative and operational. Fourteen out of sixteen of the women 
in the SRC were assigned to these roles. The majority of the roles assigned to women were related to student residence and related issues such as student transport, facilities, and living conditions. It also included academic support and financial, administrative, and related issues. This is supported by the following respondents.

Respondents 3 and 7 asserted that: "I am dealing with issues relating to residences, such as issues of WIFI in residences, issues of buses, which transport students to and from campus residences, I ensure that students stay in conducive residences" ..."I look after the well-being of students from the time they enter campus and back to residences. I deal with various matters relating to Health Clinics, lecture venues, residences, academics, and security".

Similarly, respondents 11 and 13 mentioned that: "I take care of academic matters for students, ensure that they are treated fairly; ensure the relationship between staff and students is well maintained and assist students with any issue that they may have.".. "My role is to assist all students in all aspects, academics, financial, RAC, and personal issues".

This implies that the majority of the women did not occupy senior and strategic roles such as President or Chairperson and Secretary-General. While administrative roles also play an important part in ensuring efficient day-to-day running and supporting operations of the structure, they are menial roles and not at the forefront of decision-making.

\subsection{Perceptions about women's leadership roles}

The perception that women work effectively in less demanding positions still prevails. It was noted, however, that in addition to societal perceptions, women themselves also have negative perceptions about their menial roles, which hampers their progress.

Respondent 3 asserted that: "The role wasn't too intensive; it wasn't a role that draws a lot of attention".

Respondent 1: "You still see people that don't believe in female leadership... More influential positions are given to men so women are there just to fill up the space, just to keep up with the gender quota".
Respondent 12 asserted that: "Yes, there is always a perception that women cannot hold powerful positions. We still live in a world where people view men as being superior and women in leadership are weak. We are seen as less capable".

\subsection{Challenges that hinder women into leadership positions}

The study showed that males in the SRC were power-hungry and dominating in many aspects and patriarchy was found to be promoting male dominance and women's subordination (Sathiparsad et al., 2008).

Respondent 5: "Men are power-hungry, they see themselves as the only leaders. I'm always given a motherly role as they think I have to submit myself because they are dominating".

Respondent 2: "I think the biggest factor that prevents women from attaining leadership position may be more of a patriarchal misogynistic attitude that people might have".

The masculine nature of politics placed women at a disadvantageous position. Women were seen as not very strong in presenting political arguments and therefore were intimidated by their male counterparts.

Respondent 5 articulated that: "Women do not get to talk about political positions. It is because they only think that such positions are for people who are able to lead strikes. Leadership is not about the strikes".

Respondents 2 and 3 stated: "It's not a question of women not being capable, but SRC is a political system, it is politically oriented, you don't just get an SRC position, it's a matter of the political dynamics at play"... "I think the whole transition to the structure of the SRC... Basically I had problems with various political agendas being pushed".

Political interference undermines women leaders' contribution to the struggle, promotes male dominance, and can lead to inappropriate irregular decision-making. Stereotypes about women in leadership positions were still dominant. Women were perceived to be weak and emotional rather than strong and assertive. 
Respondent 4 conveyed that: "Yes, we are stereotyped every single day... if we came with suggestions or anything like that men would say they will still look into it and see what they can do".

Respondent 5 also confirmed that: "Women are stereotyped by men, they believed women are emotional, women don't have strong power or will and they can be easily convinced or swayed. They are not looking at women's competencies and qualities, the fact that you are a woman... they think you are controlled by emotions".

Gender inequality was an obvious phenomenon in the SRC structure as men substantially outnumbered women. Secondly, gender inequality was perpetuated by gender bias, revealed by how men and women leaders were treated differently within the SRC.

Respondent 3 shared that: "Yes, there are more men than women. There's gender inequality in the sense that there are more men than women in the structure".

Whereas respondent 11 said that: "Yes, there is gender inequality, no women were given influential positions. Anything that males say goes... However, women have to put more efforts in making sure that they are treated the same as their male counterparts, whereas males don't have to go through that".

Due to the above factors, and historical and current societal factors, women developed a lack of self-esteem, which further created a barrier to promoting more women into leadership.

Respondent 8 conveyed that: "I think the main reason women do not attain leadership role is that women lack confidence... so we as women believe that we are not capable... Secondary to that is the issue that our society is always regarding women as less superior to men. Even when we grew up, men are regarded as heads of the family, and women are regarded as fits for the kitchen. Even in the political space, you find that most of the time we are expected to do catering for everyone but men have to remain in meetings and contribute politically while women are busy preparing juice and making sandwiches. It's a challenge that women do not see themselves as equal to men, but it's something that our society is responsible for".
Respondent 10: "Its self-esteem. Women do not believe in themselves, they still believe they need approval from men".

\subsection{Recommendations to the promotion of more leadership roles for women}

This sub-section emphasizes some of the recommendations, which were highlighted by respondents, to promote women into leadership positions.

The study revealed that women needed to be empowered and mobilized to join organizations, which will enhance their leadership skills. Mobilization is required because women lack the ambition to enter a nomination for the SRC election. It was revealed that women needed to work together and not against each other.

Respondent 10: "Yes, there should be more women President, Deputy President, Secretary-General... they are capable. We need to create women-only spaces where women can be in space alone to talk and come up with solutions".

Respondent 9: "Yes, there should be more women holding influential positions. There is a need to develop more leadership structures with a particular focus on women".

It was found that in the SRC gender quotas and reserved seats were not implemented. It was further found that the electoral policy did not specify rules or measures guiding the placement of women on a party list.

Respondent 7: “...should implement the 50/50 policy. Women must be given opportunities to lead programs and chair programs on campus in order to get exposure to such things".

Respondent 12: "Yes, there should be more women in powerful positions. It should be mandatory and constitutionally stipulated that 5 seats within the SRC are occupied by males and the other 5 by females".

The study found that the SRC Constitution was silent on gender equality, which should address transformation outlook and promote increased participation of women in the SRC. 
Respondent 1: "The SRC policy says nothing about gender representation...The Constitution of the $S R C$ should be a representation of what is on the outside, it must not allow a situation where you have 8 males and only 2 females in the structure".

Respondent 10 added that: "Yes there is gender inequality within the SRC Constitution, there is nothing that speaks to gender inequality, therefore gender rights are not protected by the SRC Constitution".

Gender balance could also be achieved through the Transformation Charter, which if implemented effectively, would contribute to accomplishing women's access to leadership positions.

\section{DISCUSSION}

The results indicate that the current role of women in the SRC seems to be reduced to tokenism. Their role is mere to satisfy gender representation and not to make a meaningful contribution, a phenomenon that restricts women to certain unimportant roles. This is supported by Mabokela (2003) and Ackerman and Velelo (2015) in terms of women occupying low levels of occupation. The voice of female student leaders remains excluded from the highest decision-making structures as long as they are discriminated against when it comes to holding influential decision-making portfolios. This confirms that women were aligned with more administrative roles in the SRC structure. These positions did not present opportunities for women to engage critically in strategic discussions. Women were constantly subjected to negative remarks from their male counterparts, which diminished their self-esteem even further. This concurs with the views of Lawless and Fox (2013), Schneider et al. (2016), Greyling and Steyn (2015), and Greenlee et al. (2014). Whereby women lacked self-esteem and are vulnerable to self-criticism, which affects their way of leading and therefore they are not encouraged to run for office and are not politically persuaded. They further state that the traditional view of society about women's leadership is psychological and affects their value systems and attitudes about themselves.

Results further indicate that patriarchy was occurring at the SRC and this further impacted female students attaining leadership roles. It is clear from the responses that the hindrance to political activism by women is influenced by how men dominate women in the leadership space. This concurs with Sathiparsad et al. (2008) and Francis (2009), who argued that societies are still dominated by male superiority. This is celebrated as men are continually dominating in all areas of leadership inclusive of the workplace, places of worship, politics, and various public and private spaces. It still seems deeply entrenched and transcends in various cultures, beliefs, systems, races, and settings, and such a situation remains stable for the last 20 years. This is further supported by Lawless and Fox (2013) in their argument that the nature of political socialization in the society is patriarchal and this leads to females losing interest in political involvement and equally promoting male political dominance.

As further shown in the results, women were continually stereotyped into believing that they were perceived to be too emotional, weak, and incapable to lead. There was evident bias where males were treated with respect and dignity and females were undermined and treated with disrespect. This is supported by Evans et al. (2014) and Gouws (2010) in terms of how women continue to face discrimination and remain in the minority when it comes to leadership positions. This is further supported by Eagly and Heilman (2016), who stated that men, and not women, are seen as natural-born leaders and that men were more eligible and appropriate for positions of influence. This type of stereotyping poses serious damage to women's self-esteem and can be a limiting factor to women's authority in leadership.

The findings also indicate that gender inequality is a reality and this prevents women from obtaining equal opportunities in leadership roles at the SRC. This is supported by Khuzwayo (2016), who posited it as a major obstacle, which leads to unequal sharing of resources, which is a calculated move to render women powerless and inferior in the face of women emancipation. Therefore, women experienced psychological effects of being ridiculed and minimized by men, and it contributed to women feeling inferior and yielding to such beliefs. These claims were further validated by Miller and Kraus (2004) and Lawless and Fox (2013), who asserted 
that women lack political ambition and encouragement and do not think that they are qualified to run for election into political office.

The study argues that to promote more women various factors must be taken into account. Policy change is needed and this should start with the SRC electoral policy and then the SRC Constitution. Such documents should ensure that there is the incorporation of a gender element, promotion of women empowerment with intentions to achieve maximum representation and participation of women as election candidates. This will address the issue of gender equality which is also one of the key principles upon which the South African Constitution was established (Gouws, 2010; Hills, 2015). In addition, the SRC Constitution should be categorical about gender equality.

A quota system should be introduced as asserted by respondents in the results and this can ensure equal participation of women when it comes to applying and achieving leadership roles and influences in the SRC. This coincides with Bosha (2014), who supports the notion of increasing women's participation in politics by using the quota system as this will enhance and advance women's political participation and leadership. If a quota system is not applied, women will remain oppressed as the issue of gender representation is left to organizations to decide on how they want to handle it (Hills, 2015). In addition, and in alignment to national standards of the country, South Africa's Women Empowerment and Gender Equality Bill passed in 2014 addresses issues relating to women empowerment and representation of women in decision-making structures and realization of a minimum of 50 percent representation and meaningful participation of women in decision-making structures (Minister of Women, Children and People with Disabilities, 2013).

Lastly, mentoring and training of women into leadership roles was found to be a predominant result. Schneider et al. (2016) and Lawless and Fox (2013) claimed that young women perceive themselves to be less likely fit for election into the office and that they lack ambition and do not get the encouragement to enter for elections, from either parents or their peers. Therefore, it was found that women needed structured training and development programs and workshops that will address the leadership gap, which was also evident in this study. These programs should be conducted in a women-only platform/environment to allow women to engage openly, network, and sharpen each other about their roles. Mentoring can further promote women to be politically active and will play a major role in encouraging and empowering women to pursue these leadership positions, as also supported by Moor et al. (2015).

\section{CONCLUSION}

The paper aimed to outline the challenges that hindered women from attaining leadership positions in the Student Representative Council of a large public university and provide recommendations to promote more leadership opportunities for women thereof. Challenges that hindered women from attaining leader roles included male dominance and patriarchy, political influence and interference, gender inequality and discrimination in leadership positions as well as stereotyping of women. Women were perceived as weak, too emotional, and unable to think rationally, and, therefore, incapable of holding such leadership positions. Empowerment of women-SRC leaders is a necessity for their leadership development skills. The implementation of gender policies and quotas would improve the representation of women. It was also revealed that the review of the Student Representative Council electoral policy and Constitution was required to include issues about gender equality. Therefore, the paper concludes that there are key challenges faced by women in attaining leadership positions in the Student Representative Council at the University of KwaZulu-Natal. The paper further concludes that leadership roles for women can be achieved through policy review, empowerment, and leadership skills development via leadership programs. 


\section{AUTHOR CONTRIBUTIONS}

Conceptualization: Nokwanda Jali, Sachin Suknunan, Anrusha Bhana.

Data curation: Nokwanda Jali.

Formal analysis: Nokwanda Jali.

Investigation: Nokwanda Jali, Sachin Suknunan.

Methodology: Nokwanda Jali, Sachin Suknunan, Anrusha Bhana.

Project administration: Nokwanda Jali, Sachin Suknunan.

Resources: Nokwanda Jali, Sachin Suknunan.

Software: Sachin Suknunan.

Supervision: Sachin Suknunan.

Validation: Nokwanda Jali, Sachin Suknunan, Anrusha Bhana.

Visualization: Nokwanda Jali.

Writing - original draft: Nokwanda Jali.

Writing - review \& editing: Sachin Suknunan, Anrusha Bhana.

\section{REFERENCES}

1. Ackermann, L., \& Velelo, N. (2015). The position of women in the South African labour force: an overview. Botswana Journal of African Studies, 27(1), 153-168. Retrieved from http://catalog.ihsn. org/citations/59953

2. BlackChen, M. (2015). To Lead or Not to Lead: Women Achieving Leadership Status in Higher Education. Advancing Women in Leadership, 35, 153-159. Retrieved from https://awl-ojs-tamu.tdl. org/awl/index.php/awl/article/ view/124

3. Bosha, S. L. (2014). Quota Systems and Women Political Leadership Development in Africa. Journal of African Union Studies, 3(3), 103-114.

4. Chizema, A., Kamuriwo, D. S., \& Shinozawa, Y. (2015). Women on corporate boards around the world: Triggers and barriers. The Leadership Quarterly, 26(6), 10511065. https://doi.org/10.1016/j. leaqua.2015.07.005

5. Coetzee, D. (2001). South African education and the ideology of patriarchy. South African Journal of Education, 21(4), 300-304. Retrieved from https://www. ajol.info/index.php/saje/article/ view/24919

6. Dormehl, A. (2012). BWA South African Women in Leadership Census 2012. Management Today,
30, 9-15. Retrieved from https:// www.semanticscholar.org/paper/ BWA-South-African-Women-inLeadership-Census-2012-Dormeh 1/7b96513feffdc0f035d3b8bc1cd95 5b15af1fc9e

7. Eagly, A. H., \& Heilman, M. E. (2016). Gender and leadership: Introduction to the special issue. The Leadership Quarterly, 27(3), 349-353. https://doi.org/10.1016/j. leaqua.2016.04.002

8. Evans, A. (2016a). For the Elections, We Want Women! Closing the Gender Gap in Zambian Politics. Development and Change, 47(2), 388-

341. https://doi.org/10.1111/ dech.12224

9. Evans, M., Edwards, M., Burmester, B., \& May, D. (2014). 'Not yet 50/50'-Barriers to the Progress of Senior Women in the Australian Public Service. Australian Journal of Public Administration, 73(4), 501-510. https://doi. org/10.1111/1467-8500.12100

10. Evans, S. (2016b). Women's Day 2016 meets Elections 2016: Women more important than ever. South Africa Data Journalism Academy. Retrieved from https://themediaonline.co.za/2016/08/womens-day2016-meets-elections-2016-women-more-important-than-ever/

11. Francis, S. (2009). Gender, numbers and substance: women parliamentarians and the 'politics of presence' in KwaZuluNatal. Transformation: Critical Perspectives on Southern Africa, Number 70, 119-141. http://doi. org/10.1353/trn.0.0035

12. Gouws, A. (2010). Feminism in South Africa today: Have we lost the praxis? Agenda, 24(83), 13-23. Retrieved January 6, 2020, from https://www.tandfonline.com/doi/ abs/10.1080/10130950.2010.967 6288

13. Greenlee, J. S., Holman, M. R. \& VanSickle-Ward, R. (2014). Making it personal: Assessing the impact of in-class exercises on closing the gender gap in political ambition. Journal of Political Science Education, 10(1), 48-61. http://dx.doi.org/10.1080/1551216 9.2013.859083

14. Greyling, S. C. M., \& Steyn, G. M. (2015). The Challenges facing Women aspiring for School Leadership Positions in South African Primary Schools. Gender \& Behaviour, 13(1), 6607-6620. Retrieved from https://www. ajol.info/index.php/gab/article/ view/119102

15. Gwirayi, P. (2010). Gender and Leadership: Factors influencing election into student representative council and implications for sustainable development. Journal of Sustainable Development in 
Africa, 12(2), 284-300. Retrieved from https://jsd-africa.com/Jsda/ V12No2_Spring2010_B/PDF/Gender\%20and\%20Leadership.pdf

16. Hills, J. (2015). Addressing Gender Quotas in South Africa: Women Empowerment and Gender Equality Legislation. Deakin Law Review, 20(1). https://doi. org/10.21153/dlr2015vol20no$1 \operatorname{art} 498$

17. Kasomo, D. (2012). Factors affecting women participation in electoral politics in Africa. International Journal of Psychology and Behavioral Sciences, 2(3), 57-63. http://dx.doi.org/10.5923/j. ijpbs.20120203.01

18. Keen, R., \& Cracknell, R. (2016). Women in Parliament and Government (Briefing Paper No. SN01250). The House of Commons. Retrieved from https:// commonslibrary.parliament.uk/ research-briefings/sn01250/

19. Khuzwayo, Z. (2016). Separate space: An approach to addressing gender inequality in the workplace. Journal of International Women's Studies, 17(4), 91-101. Retrieved from https://vc.bridgew.edu/jiws/ vol17/iss $4 / 7 /$

20. Lawless, J. L., \& Fox, R. L. (2013). Girls Just Wanna Not Run: The Gender Gap in Young Americans' Political Ambition. Washington, DC: Women \& Politics Institute. Retrieved from https://www. american.edu/spa/wpi/upload/ girls-just-wanna-not-run_policyreport.pdf

21. Mabokela, R. O. (2003). Donkeys of the University: Organizational culture and its impact on South African women administrators. Higher Education, 46(2), 129-145. Retrieved from https://www.jstor. org/stable/3447463

22. Maphosa, M., Tshuma, N., \& Maviza, G. (2015). Participation of Women in Zimbabwean Politics and the Mirage of Gender Equity. Ubuntu: Journal of Conflict and Social Transformation, 4(2), 127-159. Retrieved from https://www.researchgate.net/ publication/314368303_Par-
ticipation_of_Women_in_Zimbabwean_Politics_and_the_Mirage_of_Gender_Equity

23. Miles, J. M. (2010). Why We Lead: Reflections of Female Student Government Presidents (Report). Retrieved from https://eric. ed.gov/?id=ED509395

24. Miller, C. D., \& Kraus, M. (2004). Participating but Not Leading: Women's Under-Representation in Student Government Leadership Positions. College Student Journal, 38(3). Retrieved from https://eric. ed.gov/?id=EJ706690

25. Minister of Women, Children and People with Disabilities. (2013).Women Empowerment and Gender Equality Bill. Retrieved from https://static.pmg.org.za/ bill50b_2013_1_1.pdf

26. Moor, A., Cohen, A., \& Beeri, O. (2015). In Quest of Excellence, Not Power: Women's Paths to Positions of Influence and Leadership. Advancing Women in Leadership, 35, 1-11. Retrieved from https://www.researchgate. net/publication/278725803_In_ Quest_of_Excellence_Not_Power_ Women's_Paths_to_Positions_of_ Influence_and_Leadership

27. Phakeng, M. (2015). Leadership: The invisibility of African women and the masculinity of power. South African Journal of Science, 111(11/12). https://doi. org/10.17159/sajs.2015/a0126

28. Republic of South Africa. (1996). Constitution of the Republic of South Africa, Act No. 108 as of 1996. Government Gazette, 378.

29. Sathiparsad, R., Taylor, M., \& Dlamini, S. (2008). Patriarchy and family life: Alternative views of male youth in rural South Africa. Agenda, 22(76), 4-16.

30. Schneider, M. C., Holman, M. R., Diekman, A. B., \& McAndrew, T. (2016). Power, conflict, and community: How gendered views of political power influence women's political ambition. Political Psychology, 37(4), 515-531.

31. Soklaridis, S., \& López, J. (2014). Women for a Change: Closing the Leadership Gap. Academic Psychiatry, 38, 731-736. https://doi. org/10.1007/s40596-014-0215-7
32. South African Government. (2013). South Africa's National Policy Framework for Women's Empowerment and Gender Equality. Retrieved November 28, 2020, from www.info.gov.za

33. South African Union of Students (SAUS). (n.d.). Main Page. Retrieved October 20, 2020, from https://www.saus.org.za

34. Statistics South Africa. (2016). Gender equality: have the municipalities walked the talk? Retrieved October 20, 2020, from https://www.statssa.gov. $\mathrm{za} / \mathrm{p}=8137$

35. United Nations. (2015). The World's Women 2015: Trends and Statistics. New York: United Nations Department of Economic and Social Affairs, Statistics Division. Retrieved September 25, 2020, from https://www.unapcict. org/resources/ictd-infobank/ worlds-women-2015-trends-andstatistics

36. United Nations. (2017). World Population Prospects: The 2017 Revision. New York: United Nations, Department of Economic and Social Affairs, Population Division. Retrieved August 8, 2020, from https://www.un.org/ development/desa/publications/ world-population-prospects-the2017-revision.html

37. Universities South Africa (USAf). (n.d.). Home. Retrieved December 24, 2020, from https://www.usaf. ac.zal

38. University of KwaZulu-Natal (UKZN). (n.d.). Institutional Intelligence Reports. Retrieved July 15, 2020, from https://ii.ukzn.ac.za/

39. Vetten, L. (2016, August 11). Local elections 2016 show that South Africa's women continue to play second fiddle. Mail \& Guardian. Retrieved September 15, 2020, from https://mg.co.za/article/201608-11-local-elections-2016-showthat-south-africas-women-continue-to-play-second-fiddle/

40. Zuber, C. I. (2015). Reserved Seats, Political Parties, and Minority Representation. Ethnopolitics, 14(4), 390-403. https://doi.org/10.1 080/17449057.2015.1032007 